\title{
Pengaruh Pelatihan dan Kompleksitas Tugas Pada Efektivitas Penggunaan SIA Rumah Sakit Swasta di Kota Denpasar
}

\author{
Gede Bagus Dika Pradana \\ Ni Gusti Putu Wirawati \\ ${ }^{1}$ Fakultas Ekonomi dan Bisnis Universitas Udayana (Unud), Bali, Indonesia \\ email: gedebagus21@gmail.com / Telp: 082237567554 \\ ${ }^{2}$ Fakultas Ekonomi dan Bisnis Universitas Udayana (Unud), Bali, Indonesia
}

\begin{abstract}
ABSTRAK
Sistem informasi akuntansi berbasis komputer merupakan cara yang tepat dalam mengolah sistem informasi akuntansi menjadi lebih akurat, efektif, dan efisien. Tujuan penelitian ini adalah untuk mengetahui pengaruh pelatihan dan kompleksitas tugas terhadap efektifitas sistem informasi akuntansi rumah sakit swasta di kota Denpasar. penelitian ini dilakukan di 6 rumah sakit swasta di kota denpasar. Jumlah sampel yang digunakan sebanyak 57 orang menggunakan metode sample jenuh. pengumpulan data menggunakan kuisioner. analisis digunakan uji regresi linear berganda. berdasarkan hasil analisis ditemukan bahwa pelatihan berpengaruh positif dan signifikan pada efektivitas penggunaan sistem informasi akuntansi. Hal ini berarti semakin sering melakukan pelatihan maka efektivitas penggunaan sistem informasi akuntansi semakin tinggi. Kompleksitas tugas berpengaruh positif dan signifikan terhadap efektivitas penggunaan sistem informasi akuntansi.

Kata kunci : Pelatihan, kompleksitas tugas, efektivitas penggunaan sistem informasi akuntansi
\end{abstract}

\begin{abstract}
Computer-based accounting information system is the right way to process accounting information systems to be more accurate, effective, and efficient. The purpose of this study was to determine the effect of training and the complexity of the task on the effectiveness of accounting information systems of private hospitals in Denpasar City. This research was conducted in 6 private hospitals in the city of Denpasar. The number of samples was 57 people using the saturated sample method. Data collection using questionnaires. Analysis used multiple linear regression test. Based on the results of the analysis it was found that training had a positive and significant effect on the effectiveness of the use of accounting information systems. This means that the more frequent the training, the higher the effectiveness of the use of accounting information systems. Task complexity has a positive and significant effect on the effectiveness of using accounting information systems.

Keywords: training, task complexity, effectiveness of using accounting information systems.
\end{abstract}

\section{PENDAHULUAN}

Sistem informasi akuntansi berbasis komputer merupakan cara yang tepat dalam mengolah data informasi menjadi lebih akurat, efektif, dan efisien. Sistem informasi akuntansi berbasis komputer telah menggantikan cara lama dalam 
Gede Bagus Dika Pradana dan Ni Gusti Putu Wirawati. Pengaruh...

mengolah data informasi yang masih tradisional atau manual. Pada sistem manual, mengolah data atau informasi menjadi lebih lama dan mahal karena terkendala pada waktu, tenaga, dan biaya yang dibutuhkan. Sistem informasi akuntansi adalah sistem yang menyediakan informasi akuntansi dan keuangan beserta informasi lainnya yang diperoleh dari proses rutin transaksi akuntansi (TMbooks, 2015:2). Sistem informasi akuntansi adalah sebuah sistem yang memproses data dan transaksi guna menghasilkan informasi yang bermanfaat untuk merencanakan, mengendalikan, mengoperasikan bisnis. Informasi tersebut dikomunikasikan kepada para pembuat keputusan. Penggunaan efektivitas sistem informasi akuntansi tergantung dari seberapa baik pengguna mengetahui sistem, layanan pendukung dari penyedia sistem informasi dan kapasitas dari sistem itu sendiri.

Sistem informasi akuntansi yang dirancang dan diterapkan oleh Rumah Sakit dapat dikatakan efektif apabila dapat memadai dengan diterapkannya unsur pokok sistem informasi akuntansi salah satunya adalah sumber daya manusia. Karyawan yang kompeten yang memiliki keahlian serta keterampilan di bidang komputerisasi dan alat-alat teknis kedokteran untuk melaksanakan prosedurprosedur yang diperlukan untuk beroperasinya suatu sistem informasi akuntansi yang baik dalam Rumah Sakit. Selain karyawan peralatan seperti sistem komputer dan alat kedokteran lainnya juga dapat menunjang keefektifan penggunaan sistem informasi akuntansi dengan dipergunakannya peralatan tersebut secara maksimal dalam mengelola data menjadi informasi yang diperlukan dalam proses pengambilan keputusan. Sistem komputerisasi dilakukan dalam pengelolaan data menjadi informasi, hal ini dimaksudkan agar tercapai efesiensi dalam hal tenaga, 
waktu dan biaya serta dapat menekan resiko kesalahan bila dibandingkan dengan proses pengelolaan secara manual.

\section{METODE PENELITIAN}

Lokasi penelitian dilakukan pada Rumah Sakit Swasta di Kota Denpasar. Tempat ini dipilih karena Rumah Sakit sebagai salah satu institusi pelayanan umum yang membutuhkan keberadaan suatu sistem informasi yang akurat dan handal, serta cukup memadai untuk meningkatkan pelayanan kepada para pasien serta lingkungan yang terkait lainnya.

Objek penelitian ini adalah Pelatihan, Kompleksitas Tugas dan Efektivitas Sistem Informasi Akuntansi. Objek ini dipilih karena perilaku manusia merupakan salah satu faktor dominan dalam pencapaian tujuan perusahaan dan efektivitas merupakan ukuran berhasil tidaknya perusahaan mencapai tujuan yang telah ditetapkan.

Sugiyono $(2014 ; 156)$ menyatakan bahwa variabel merupakan objek sebuah pengamatan atau fenomena yang sedang diteliti. Digunakan tiga variabel dalam penelitian ini, yaitu variabel dependen/terikat (Y) merupakan variabel yang menjadi akibat karena berubahnya variabel independen. Variabel dependen yang digunakan dalam penelitian ini adalah efektivitas SIA (Y). Variabel independen/bebas (X) merupakan variabel yang dapat mengakibatkan perubahan pada variabel dependen. Digunakan dua variabel independen, yaitu pelatihan (X1) dan kompleksitas tugas (X2).

Operasional variabel merupakan definisi yang diberikan kepada variabel dengan tujuan memberikan arti atau menspesifikasikannya. Adapun variabel yang 
Gede Bagus Dika Pradana dan Ni Gusti Putu Wirawati. Pengaruh...

dianalisis dalam penelitian ini didefinisikan sebagai berikut. Pelatihan $\left(\mathrm{X}_{3}\right)$ adalah suatu kegiatan untuk memperbaiki kemampuan kerja seseorang dalam kaitannya dengan aktivitas ekonomi. Latihan membantu pegawai/karyawan dalam memahami suatu pengetahuan praktis dan penerapannya, guna meningkatkan keterampilan, kecakapan dan sikap yang dipergunakan oleh organisasi dalam usaha mencapai tujuannya. Indikator yang digunakan untuk mengukur pelatihan dalam penelitian ini yaitu pengalaman kerja karyawan dan pengetahuan dan keahlian yang dimiliki karyawan.

Kompleksitas tugas $\left(\mathrm{X}_{2}\right)$ adalah persepsi individu tentang kesulitan suatu tugas yang disebabkan oleh terbatasnya kemampuan untuk melaksanakan suatu tugas, daya ingat dan kemampuan untuk mengintegrasikan masalah yang dimiliki oleh seorang pembuat keputusan. Indikator yang digunakan untuk mengukur kompleksitas tugas dalam penelitian ini yaitu pemahaman tugas karyawan terhadap pekerjaan dan kemampuan atau keahlian yang dimiliki karyawan. Efektivitas sistem informasi akuntansi (Y) merupakan suatu komponen organisasi yang mengumpulkan, mengklasifikasikan, mengolah, menganalisa dan mengkomunikasikan informasi finansial dan pengambilan keputusan yang relevan bagi pihak luar perusahaan dan pihak ekstern. Sistem informasi akuntansi dapat dikatakan sebagai suatu kondisi yang menyatakan tingkat keberhasilan suatu pelaksanaan aktivitas atau kumpulan sumber daya, seperti manusia dan peralatan, yang dirancang untuk mengubah data keuangan dan data lainnya menjadi informasi yang dikomunikasikan kepada berbagai pihak pengambil keputusan untuk mencapai tujuan yang telah ditetapkan. Indikator yang digunakan untuk 
mengukur efektivitas sistem informasi akuntansi dalam penelitian ini yaitu relevan, kualitas laporan keuangan, dan keamanan data.

Populasi adalah wilayah generalisasi yang terdiri atas objek atau subjek yang mempunyai kualitas dan karakteristik tertentu yang ditetapkan oleh peneliti untuk dipelajari dan kemudian ditarik kesimpulannya (Sugiyono, 2014:115). Populasi yang digunakan dalam penelitian ini adalah seluruh karyawan Rumah Sakit Swasta di Kota Denpasar pada bagian administrasi umum dan keuangan yang menggunakan sistem informasi berbasis komputer. Jumlah populasi dalam penelitian adalah 57 orang.

Sampel adalah bagian dari jumlah dan karakteristik yang dimiliki populasi tersebut (Sugiyono, 2017:81). Metode penentuan sampel yang digunakan dalam penelitian ini adalah non propabilitysampling dengan teknik sampling jenuh. Teknik sampling jenuh merupakan teknik penentuan sampel apabila semua anggota populasi digunakan sebagai sampel dikenal juga dengan istilah sensus (Sugiyono, 2017:85). Alasan metode ini digunakan karena populasi relatif kecil dan dipertimbangkan dari ketersediaan waktu yang memungkinkan untuk dilakukan secara keseluruhan.

Berdasarkan jenisnya (Sugiyono, 2014:13), jenis data yang digunakan dalam penelitian ini yaitu data kualitatif merupakan data-data yang tidak berupa angka-angka, hanya berupa penjelasan atau keterangan dan tidak diukur dengan satuan hitung yang berhubungan dengan penulisan laporan atau data yang berupa kata-kata, skema, gambar. Data kualitatif dalam penelitian ini adalah penjelasan dari hasil pengolahan data kuesioner. Data kuantitatif merupakan data yang 
Gede Bagus Dika Pradana dan Ni Gusti Putu Wirawati. Pengaruh...

dinyatakan dalam bentuk angka-angka dan dapat diukur dengan satuan hitungan atau data kualitatif yang diangkakan. Data kuantitatif dalam penelitian ini adalah hasil kuesioner berupa angka-angka dari masing-masing jawaban responden RSUP Sanglah Kota Denpasar.

Berdasarkan sumbernya (Sugiyono, 2014:193), sumber data yang digunakan dalam penelitian ini yaitu data primer adalah sumber data penelitian yang diperoleh secara langsung dari sumbernya baik individu maupun kelompok seperti hasil jawaban kuesioner. Data primer dalam penelitian ini adalah hasil jawaban kuesioner oleh responden yang diangkakan. Data sekunder adalah data yang dikumpulkan secara tidak langsung memberikan data kepada pengumpul data, misalnya lewat orang lain atau lewat dokumen. Data sekunder yang dimaksud dalam penelitian ini adalah data yang dikumpulkan dari sumber luar yaitu struktur organisasi dan tugas masing-masing karyawan.

Kuesioner yaitu metode pengumpulan data yang dilakukan dengan cara memberi seperangkat pertanyaan tertulis kepada responden untuk dijawab. Kuesioner yang desebarkan berupa daftar pertanyaan dan pertanyaan tertulis kepada responden mengenai pengaruh tingkat pendidikan, pengalaman kerja, pelatihan, jabatan, insentif, usia, skill dan kompleksitas tugas terhadap efektivitas sistem informasi akuntansi.

Teknik analisis data yang digunakan dalam penelitian ini adalah teknik analisis regresi linear berganda. Analisis tersebut dapat dihitung dengan menggunakan alat bantu Statistical Package for Social Science (SPSS). Regresi Linear untuk menghitung besarnya pengaruh variabel $\mathrm{X}$ dan $\mathrm{Y}$, yang diukur 
dengan menggunakan koefisien regresi, metode ini menghubungkan variabel dependen dengan variabel independen. Untuk membuktikan kebenaran adanya pengaruh variabel independen dan dependen digunakan analisis regresi dimana variabel bebas $\left(\mathrm{X}_{1}\right)$ Pelatihan, $\left(\mathrm{X}_{2}\right)$ Kompleksitas Tugas dan $(\mathrm{Y})$ adalah Efektivitas Sistem Informasi Akuntansi.

Analisis regresi linear berganda digunakan untuk menguji hipotesis penelitian ini, dengan rumus persamaan sebagai berikut:

$\mathrm{Y}=\alpha+\beta_{1} \mathrm{X}_{1}+\beta_{2} \mathrm{X}_{2}$

Keterangan:

Y : Efektivitas Sistem Informasi Akuntansi

$\alpha$ : konstanta

$\beta$ : Koefisien regresi variabel bebas

$\mathrm{X}_{1: \text { Pelatihan }}$

$\mathrm{X}_{2:}$ Kompleksitas tugas

Ei : Variabel pengganggu

Uji validitas digunakan untuk mengukur sah atau tidaknya suatu kuesioner. Suatu kuesioner dikatakan valid jika pertanyaan pada kuesioner mampu mengungkapkan sesuatu yang akan diukur oleh kuesioner tersebut. Pengujian validitas dilaksanakan dengan menghitung korelasi antara skor masingmasing butir pertanyaan dengan total skor, sehingga dapat dinilai pearson correlation. Apabila korelasi antara masing-masing skor butir pertanyaan mengajukan hasil yang signifikan, maka dapat disimpulkan bahwa masing-masing butir pertanyaan valid. Validnya suatu kuesioner dapat dilihat dari nilai $\mathrm{r}_{\text {hitung }}$ lebih besar dari 0,3 (Ghozali, 2016:55)

Reliabilitas adalah alat untuk mengukur suatu kuesioner yang merupakan indikator dari variabel atau konstruk. Suatu kuesioner dikatakan reliable atau 
Gede Bagus Dika Pradana dan Ni Gusti Putu Wirawati. Pengaruh...

handal jika jawaban seseorang terhadap pernyataan adalah konsisten atau stabil dari waktu ke waktu. Uji reabilitas dilakukan terhadap instrument dengan koefisien Cronbach'c alpha lebih besar dari 0,6 maka instrument yang digunakan reliable (Ghozali, 2013:48).

Uji Asumsi Klasik dimasukkan agar model regresi dapat dijadikan alat estimasi yang tidak bias. Penguji asumsi klasik yang digunakan dalam penelitian ini meliputi: uji normalitas bertujuan untuk menguji apakah dalam model regresi variabel pengganggu atau residual memiliki distribusi normal. Model regresi yang baik adalah memiliki distribusi residual yang normal atau mendekati normal. Pengujian normalitas dilakukan dengan uji Kolmogorov-Sminarnov dimana data yang terdistribusi normal akan memiliki nilai Sig (2-tailed) yang lebih besar dari 0,05. Untuk menguji normalitas dilaksanakan dengan bantuan program SPSS. UJi multikolinearitas bertujuan untuk menguji apakah pada model regresi ditemukan adanya kolerasi antar variabel bebas (independen). Model regrasi yang baik seharusnya tidak terjadi korelasi diantara variabel independen. Untuk mendeteksi ada tidaknya korelasi atara semua variabel bebas dapat dilihat dari nilai tolerance dan nilai variance inflation factor (VIF). Jika nilai tolerance lebih besar dari 10 persen $(0,10)$ atau VIF kurang dari 10 , maka dikatakan tidak ada multikolinieritas. Untuk menguji multikolinearitas dilaksanakan dengan bantuan program SPSS. Uji Heteroskedastisitas bertujuan menguji apakah regresi terjasi ketidaksamaan varian dari residual satu pengamatan ke pengamatan yang lain. Jika varian dari residual satu pengamatan ke pengamatan lain tetap, maka disebut homoskedastisitas dan jika berbeda disebut heteroskedastisitas. Model regresi yang baik adalah yang 
homokesdatisitas atau terjadi heteroskesdatisitas. Untuk mendeteksi ada atau tidaknya heteroskedastisitas digunakan metode glejser. Model ini dilakukan dengan meregres nilai absolut residual terhadap variabel independen. Jika variabel independen signifikan secara statistik mempengaruhi variabel dependen, maka ada indikasi terjadi heteroskedastisitas (Ghozali, 2013:139). Untuk menguji heteroskedastisitas dilaksanakan dengan bantuan program SPSS.

Uji F digunakan untuk menguji kelayakan model. Uji F dilakukan dengan melihat signifikansi pada tabel Annova dengan program SPSS. Hasil Uji F yang signifikan apabila nilai sig kurang dari 0,05 maka model dapat dikatakan layak (Ghozali, 2016:96). Untuk pengujian hipotesis digunakan uji $\mathrm{t}$ (t-test), yaitu Independent T-test dengan menggunakan bantuan program SPSS karena sampel yang diuji terdiri dari dua kelompok yang saling independen dan bertujuan untuk mengetahui ada atau tidaknya perbedaan persepsi antara kelompok sampel. Independent T-test prinsipnya ingin mengetahui apakah ada perbedaan mean antara dua sampel dengan membandingkan dua mean sampelnya. Pengujian hipotesis uji beda t-test dengan sampel independen (Independent T-test) digunakan untuk menentukan apakah sampel yang tidak berhubungan memiliki nilai rata-rata yang berbeda.

Ada dua tahap analisis yang digunakan dalam uji beda, yaitu. Pertama, menguji apakah asumsi varian populasi kedua sampel tersebut sama atau berbeda dengan melihat nilai Levene test. Kedua, dengan melihat nilai t-test untuk menentukan apakah terdapat perbedaan nilai rata-rata secara signifikan. 
Gede Bagus Dika Pradana dan Ni Gusti Putu Wirawati. Pengaruh...

Pengambilan keputusan berdasarkan jika p-value ( $\mathrm{sig}$ ) > 0,05 maka $\mathrm{H}_{1}$ ditolak dan jika $p$-value (sig) < 0,05 maka $\mathrm{H}_{1}$ diterima.

\section{HASIL DAN PEMBAHASAN}

Deskripsi variabel penelitian menjabarkan informasi masing-masing variabel penelitian dan statistik deskriptif masing-masing variabel untuk memberikan gambaran tentang karakteristik masing-masing variabel penelitian, antara lain mean, minimum, maksimum dan standar deviasi. Pengukuran rata-rata (mean) merupakan cara yang paling umum digunakan untuk mengukur nilai sentral suatu distribusi data. Nilai minimum merupakan nilai yang paling rendah dari suatu distribusi data. Nilai maksimum merupakan nilai yang tertinggi dari suatu distribusi data. Sedangkan standar deviasi adalah perbedaan nilai data yang diteliti dengan nilai rata-rata.

Berdasarkan statistik deskriptif diperoleh nilai minimum dari pelatihan sebesar 12 sedangkan nilai maksimum sebesar 20. Nilai rata-rata dari pelatihan sebesar 15,22 dan standar deviasi sebesar 2,73. Berdasarkan statistik deskriptif diperoleh nilai minimum dari kompleksitas tugas sebesar 12 sedangkan nilai maksimum sebesar 20. Nilai rata-rata dari kompleksitas tugas sebesar 15,0 dan standar deviasi sebesar 2,3. Berdasarkan statistik deskriptif diperoleh nilai minimum dari efektivitas penggunaan SIA sebesar 12 sedangkan nilai maksimum sebesar 20. Nilai rata-rata dari efektivitas penggunaan SIA sebesar 15,21 dan standar deviasi sebesar 2,11. Pengujian instrumen penelitian menggunakan uji validitas dan uji reliabilitas. 
Uji validitas merupakan pengujian instrumen penelitian sebagai suatu derajat ketepatan alat ukur penelitian tentang inti atau arti sebenarnya yang diukur. Tinggi rendahnya validitas menunjukkan sejauh mana data yang terkumpul tidak menyimpang dari gambaran tentang variabel yang dimaksud. Suatu kuesioner dikatakan valid jika tiap butir pernyataan mampu mengungkapkan sesuatu yang akan diukur oleh kuesioner. Pengujian validitas tiap butir menggunakan analisis item yaitu, mengkorelasikan skor tiap butir atau faktor dengan skor total yang merupakan jumlah tiap skor butir. Syarat minimum suatu kuisioner untuk memenuhi validitas adalah jika korelasi antara butir dengan skor total tersebut positif dan nilainya lebih besar dari 0,30 . Instrumen-instrumen pada setiap variabel dalam penelitian ini memiliki nilai korelasi diatas 0,30 sehingga dapat disimpulkan bahwa, seluruh butir dalam instrumen penelitian ini dikatakan valid atau dapat dinyatakan layak digunakan sebagai alat ukur.

Reliabilitas adalah derajat ketepatan, ketelitian atau keakuratan yang ditunjukkan oleh instrument pengukuran dimana pengujiannya dapat dilakukan secara internal, yaitu pengujian dengan menganalisis konsistensi butir-butir yang ada. Cronbach's Alpha untuk setiap variabel lebih besar dari 0,6. Jadi, dapat dinyatakan bahwa seluruh variabel telah memenuhi syarat reliabilitas atau dapat dikatakan reliabel sehingga, dapat digunakan untuk melakukan penelitian.

Nilai Kolmogorov-Smirnov (K-S) adalah 1,253 dan nilai asymp.Sig (2tailed) sebesar 0,087. Nilai tersebut menunjukkan bahwa secara statistik nilai Asymp.sig (2-tailed) lebih besar dari 0,05 yang berarti data terdistribusi secara normal. 
Gede Bagus Dika Pradana dan Ni Gusti Putu Wirawati. Pengaruh...

Uji Multikolinearitas bertujuan untuk menguji apakah di dalam model regresi ditemukan adanya korelasi antar variabel bebas. Model regresi yang baik seharusnya tidak terjadi korelasi diantara variabel bebas. Suatu model regresi dapat dikatakan baik jika tidak terjadi multikolinearitas di dalamnya. Model regresi yang bebas dari multikolinearitas adalah yang memiliki nilai variance inflaction factor (VIF) tidak lebih dari 10 dan mempunyai angka tolerance lebih dari $10 \%$.

Tabel 1.

Uji Multikolinearitas

\begin{tabular}{lllc}
\hline & Model & & Collinearity Statistics \\
& & Tolerance & VIF \\
\hline 1 & $\mathrm{X} 1$ & 0,987 & 1,013 \\
& $\mathrm{X} 2$ & 0,987 & 1,013 \\
\end{tabular}

Sumber: Data diolah, 2018

Nilai tolerance variabel bebas lebih dari $10 \%$ atau 0,1 dimana nilai tolerance dari dibawah 10. Dengan demikian dapat disimpulkan tidak terjadi multikolinearitas diantara variabel bebas dalam penelitian ini.

Uji heteroskedastisitas dilakukan untuk mengetahui apakah dalam model regresi terjadi ketidaksamaan varian. Uji ini dapat dianalisis melalui uji gletser dengan melihat tingkat signifikansi, jika tingkat signifikansi berada di atas 0,05 maka model regresi ini bebas dari masalah heterokedastisitas. Tingkat signifikansi berada di atas 0,05. Dengan demikian dapat dikatakan bahwa dalam model regresi ini tidak terdapat heterokedastisitas.

Analisis regresi linear berganda digunakan untuk menguji hipotesis penelitian ini, dengan rumus persamaan sebagai berikut: 
$\mathrm{Y}=\alpha+\beta_{1} \mathrm{X}_{1}+\beta_{2} \mathrm{X}_{2}$

$Y=2,350+0,512 X_{1}+0,337 X_{2}$

Berdasarkan hasil penelitian menunjukkan bahwa pelatihan berpengaruh positif dan signifikan pada efektivitas penggunaan SIA sehingga hipotesis pertama dalam penelitian ini diterima. Hasil penelitian memberikan makna bahwa semakin sering melakukan pelatihan, maka semakin tinggi tingkat efektivitas penggunaan SIA, begitu juga sebaliknya semakin jarang melakukan pelatihan maka semakin rendah tingkat efektivitas penggunaan SIA.

Pelatihan adalah suatu kegiatan untuk memperbaiki kemampuan seorang karyawan dengan cara meningkatkan pengetahuan dan keterampilan karyawan dalam menjalankan suatu pekerjaan (Soeprihanto, 2010:374). Dengan diadakan program pelatihan dan pendidikan kerja pada karyawan maka hal ini untuk menmbah dan melengkapi keterampilan yang tepat melaksanakan pekerjaanya serta menggunakan peralatan yang disediakan oleh pihak perusahaan (Mulyadi, 2015:104). Hasil Penelitian yang mendukung teori ini adalah Windha dkk (2013) menyatakan pelatihan berpengaruh positif dan signifikan terhadap efektivitas penggunaan sistem informasi akuntansi.

Berdasarkan hasil penelitian menunjukkan bahwa kompleksitas tugas berpengaruh positif dan signifikan pada efektivitas penggunaan SIA sehingga hipotesis kedua dalam penelitian ini diterima. Hasil penelitian memberikan makna bahwa semakin tinggi kompleksitas tugas, maka semakin tinggi tingkat efektivitas penggunaan SIA, begitu juga sebaliknya semakin rendah kompleksitas tugas maka semakin rendah tingkat efektivitas penggunaan SIA 
Gede Bagus Dika Pradana dan Ni Gusti Putu Wirawati. Pengaruh...

Kompleksitas adalah sulitnya suatu tugas yang disebabkan oleh terbatasnya kapabilitas, dan daya ingat serta kemampuan untuk mengintegrasikan masalah yang dimiliki oleh seorang pembuat keputusan. Tingkat kesulitan tugas dan struktur tugas merupakan dua aspek penyusun dari kompleksitas tugas. Tingkat sulitnya tugas selalu dikaitkan dengan banyaknya informasi tentang tugas tersebut, sementara struktur adalah terkait dengan kejelasan informasi (information clarity) (Yendrawati,2015:3). Hasil penelitian yang mendukung teori ini adalah dalam penelitian Herlina (2011) menyatakan bahwa kompleksitas tugas berpengaruh positif dan signifikan terhadap efektivitas penggunaan sistem informasi akuntansi. Penelitian ini sebaiknya dapat menjadi rujukan untuk memberi suatu sumbangan konseptual terutama untuk civitas akademika lainnya dalam hal mampu mengembangkan ilmu pengetahuan untuk perkembangan dan kemajuan dalam dunia pendidikan khususnya bidang akuntansi.

\section{SIMPULAN}

Berdasarkan hasil analisis yang diperolah dalam penelitian ini, maka dapat disimpulkan sebagai berikut. Pelatihan berpengaruh positif dan signifikan terhadap efektivitas penggunaan SIA. Hal ini berarti semakin sering melakukan pelatihan maka efektivitas penggunaan SIA semakin tinggi. Kompleksitas tugas berpengaruh positif dan signifikan terhadap efektivitas penggunaan SIA. Hal ini berarti semakin meningkat kompleksitas tugas maka efektivitas penggunaan SIA semakin tinggi.

Berdasarkan hasil penelitian maka dapat disarankan sebagai berikut. Diharapkan manager keuangan dan administrasi mengajukan ke pimpinan 
manajemen agar staf akunting diberikan pelatihan secara berkala untuk mengantisipasi perkembangan akuntansi yang sesuai dengan kebutuhan pasar. Bagi peneliti berikutnya dapat menambahkan variabel bebas yang berpengaruh terhadap efektivitas penggunaan SIA seperti kompensasi.

\section{REFERENSI}

Arnila Baktiyari Gusti Ayu. (2013). Pengaruh Jabatan, Usia, Pengalaman, Tingkat Pendidikan Dan Skill Terhadap Efektivitas Sistem Informasi Akuntansi Pada PT.PLN (persero) Area Bali Selatan. Skripsi. Jurusan Akuntansi, Fakultas Ekonomi Universitas Warmadewa, Denpasar.

Arya Pradipta. (2013). Pengaruh Komitmen, Motivasi Kompleksitas Tugas dan Budaya Suportif Terhadap Kepuasan Kerja. Jurnal Media Bisnis, ST1E Trisakti.

Dwijayanthi Diah Maha \& I. B. Dharmadiaksa. (2013). Pengaruh insentif, tingkat pendidikan, pelatihan dan pengalaman kerja pada kinerja individu pengguna sistem informasi akuntansi SKPD Dispenda Kota Denpasar. E-Jurnal Akuntansi Universitas Udayana, 4 (2). 332-344.

Eny Prajanti, Kartika Hendra, \& Siti Nurlela. (2014). Pengaruh Sistem Informasi, Gaya Kepemimpinan dan Kompleksitas Tugas Terhadap Kinerja Karyawan. Jurnal Paradigma, 12 (01). 57-70.

Evilia Herlina Putu, (2011), Pengaruh Gender, jabatan, tingkat pendidikan, pengalaman, dan kompleksitas tugas pada efektivitas sistem informasi akuntansi Rumah Sakit di Kabupaten Gianyar, E-Jurnal Akuntansi Universitas Udayana, 5 (3). 320-336.

Ghozali, Imam, (2013), Aplikasi Analisis Multivariate Dengan Program IBM SPSS 21, Penerbit Universitas Diponogoro, Semarang.

Handoko, T. Hani, (2015), Manajemen, Edisi kedua, Cetakan Keduapuluh Tujuh, BPFE, Yogyakarta.

Hasibuan H. Malayu S.P, (2013), Manajemen Sumber Daya Manusia, Edisi Revisi Penerbit PT Bumi Aksara.

Kinicki Angelo dan Robert Kreitner (2005), Prilaku Organisasi , Edisi kelima, Jakarta: Salemba Empat 
Krismiaji, (2010), Sistem Informasi Akuntansi, Edisi Ketiga, Penerbit UPP Stim. YKPN, Yogyakarta

lubis Arfan Ikhsan. (2010). Akuntansi Keperilakuan, Edisi kedua, Penerbit Salemba Empat, Jakarta.

Mardiasmo. (2009). Akuntansi Sektor Publik. Yogyakarta: ANDI.

Mulyadi. (2015). Manajemen Sumber Daya Manusia, Bogor. IN MEDIA

Reni Yendrawati \& Dheana Kurnia Mukti. (2015). Pengaruh Gender, Pengalaman Auditor, Kompleksitas Tugas, Tekanan Ketaatan, Kemampuan Kerja dan Pengetahuan Auditor terhadap Audit Jugement, Jumal Inovasi dan Kewirausahaan, 4(1),1-8.

Sanjaya Ari I Made, (2013). Pengaruh komimikasi, pendidikan, pelatiham, dan lingkungan kerja fisik terhadap kinerja karyawan pada PT. Pos Indonesia di Gianyar, Skripsi Fakultas Ekonomi Universitas Warmadewa, Denpasar.

Siti Jamilah, Zaenal Fanani, \& Grahita Chandrarin. (2007). pengaruh Gender, Tekanan Ketaatan, dan Kompleksitas Tugas Terhadap Audit Judgment, Simposium Nasional Akuntansi X Makasar, 26-28 juli 2007.

Soeprihanto Jhon \& Murti Sumarni. (2010). Pengantar Bisnis, Cetakan keenam. Penerbit Liberty Yogyakarta.

Sugiyono. (2015). Metode Penelitian bisnis, Cetakan Ke-18, Penerbit Alfabeta, Bandung.

Sujarweni V. Wiratna. (2015). Sistem Akuntansi, Cetakan Pertama, Penerbit Pustaka Baru Press, Yogyakarta.

Sutrisno H. Edy. (2011). Manajemen Sumber Daya Manusia, Edisi Kepertama Cetakan Ketiga, Jakarta: Kencana.

TMbooks. (2015). Sistem Informasi Akuntansi - Konsep dan Penerapan, Edisi Pertama, Yogyakarta: ANDI.

Windha Fahmiswari A. A Istri, Ida Bagus Dharmadhiaksa. (2013). Pengaruh kinerja individual karyawan terhadap efektivitas pengguna sistem informasi akuntansi, E-Jurnal Akuntansi Universitas Udayana, 5 (3). 690-706.

Wing Wahyu Winarno. (2007). Sistem Informasi Akuntansi, Edisi kedua, Cetakan Pertama Penerbit UPP Stim YKPN, Yogyakarta. 
ISSN: 2302-8556

E-Jurnal Akuntansi Universitas Udayana Vol.25.3.Desember (2018): 1994- 2010

Adisanjaya Komang. (2017). Pengaruh kemampum personal, pelatihan dan pendidikan serta pemanfaatan teknologi terhadap efektivitas sistem informasi akuntansi pada Mini Market Bali Mardana. 